\title{
Corynebacterium glaucum sp. nov.
}

\author{
Correspondence \\ A. F. Yassin \\ yassin@mibi03.meb.uni-bonn.de
}

\author{
A. F. Yassin, ${ }^{1}$ R. M. Kroppenstedt ${ }^{2}$ and W. Ludwig ${ }^{3}$ \\ ${ }^{1}$ Institut für Medizinische Mikrobiologie und Immunologie der Universität Bonn, Sigmund-Freud- \\ Straße 25, 53127 Bonn, Germany \\ ${ }^{2} \mathrm{DSMZ}$ - Deutsche Sammlung von Mikroorganismen und Zellkulturen, Mascheroder Weg $1 \mathrm{~b}$, \\ D-24138 Braunschweig, Germany \\ ${ }^{3}$ Lehrstuhl für Mikrobiologie Technische Universität München, am Hochanger 4, 85350 \\ Freising, Germany
}

\begin{abstract}
A bacterial strain, strain IMMIB R-5091 ${ }^{\top}$, isolated from a cosmetic dye was characterized by phenotypic and molecular taxonomic methods. Chemotaxonomic investigations revealed the presence of cell-wall chemotype IV and short-chain mycolic acids consistent with the genus Corynebacterium. Comparative 16S rRNA gene sequencing showed that the isolate constitutes a distinct subline within the genus Corynebacterium, displaying $>2.6 \%$ sequence divergence from established species. The isolate could be distinguished from other members of the genus Corynebacterium by biochemical tests. Based on both phenotypic and phylogenetic evidence, it is proposed that strain IMMIB R-5091 ${ }^{\top}$ ( = DSM $44530^{\top}=$ NRRL B-24142 ${ }^{\top}$ ) be classified as the type strain of a novel species, Corynebacterium glaucum sp. nov.
\end{abstract}

The use of chemical markers (Schleifer \& Kandler, 1972; Keddie \& Cure, 1977; Collins et al., 1977, 1982a, b) in combination with a phylogenetic approach based on $16 \mathrm{~S}$ rRNA gene sequence analyses (Pascual et al., 1995; Ruimy et al., 1995) and improved phenotypic criteria (e.g. miniaturized tests) have not only resulted in a much improved taxonomy of the genus Corynebacterium but have also proved invaluable for the delineation of novel taxa. During the past decade, a considerable number of novel corynebacterial species have been described (e.g. Riegel et al., 1993, 1997; Funke et al., 1997b, 1998; Fernández-Garayzábal et al., 1998; Wattiau et al., 2000; Collins et al., 2001; Brennan et al., 2001). The vast majority of these newly described species have been isolated from human clinical and veterinary sources (Funke et al., 1997b). In addition, corynebacteria are found in a broad variety of habitats such as soil, plants and food products. During the course of identification of taxonomically problematic Actinobacteria from different sources, using chemical and molecular taxonomic approaches, a strain designated IMMIB R-5091 ${ }^{\mathrm{T}}$ appeared to represent a novel corynebacterial species. Based on the reported findings, the name Corynebacterium glaucum sp. nov. is proposed for this isolate.

Strain IMMIB R-5091 ${ }^{\mathrm{T}}$ was isolated from a cosmetic dye. The isolate was cultured on brain heart infusion (BHI) agar,

Published online ahead of print on 4 October 2002 as DOI 10.1099/ ijs.0.02394-0.

Abbreviation: $\mathrm{BH}$, brain heart infusion.

The GenBank accession number for the $16 \mathrm{~S}$ rRNA sequence of strain IMMIB R-5091 ${ }^{\top}$ is AJ431634.
BHI agar supplemented with $1 \%$ Tween 80 , Columbia blood agar supplemented with $5 \%$ sheep blood and trypticase soy agar (Oxoid) to determine its morphological properties. Air-dried smears from BHI agar cultures were stained by the Gram and Ziehl-Neelsen methods in order to determine the Gram reaction and acid-fastness. Fermentation tests were performed using the API CORYNE and API 20 STREP systems (bioMérieux) and the MINITEK system (Becton Dickinson). Enzyme reactions and acid production from carbohydrates were read after $72 \mathrm{~h}$ incubation at $37^{\circ} \mathrm{C}$. Further enzyme reactions were studied by means of the API ZYM system (bioMérieux). GC analysis of fermentation products was carried out with $7 \cdot 0 \mathrm{ml}$ culture in peptone/yeast extract/glucose (PYG) broth incubated for 7 days as described by Holdeman et al. (1977). The isomeric form of diaminopimelic acid was determined by the methods of Becker et al. (1964) and whole-cell sugars was determined by the method of Lechevalier (1968). Lipids were extracted using acid methanolysis and mycolic acids were detected with TLC as described by Minnikin et al. (1980). Non-hydroxylated fatty acids were purified, identified and quantified by GC as described by Yassin (1988). Menaquinones were extracted, purified and identified according to Collins et al. (1977). Phospholipids were extracted, purified and identified as described previously (Yassin et al., 1993).

DNA was isolated and purified as described previously (Yassin et al., 2000). G + C contents were determined by HPLC (Mesbah et al., 1989). Genomic DNA extraction, PCR-mediated amplification of the 16S rDNA and purification of PCR products were carried out using procedures 
described previously (Rainey et al., 1996). Purified PCR products were sequenced using a Taq DyeDeoxy Terminator cycle sequencing kit (Applied Biosystems) as described in the manufacturer's protocol. An Applied Biosystems 310 DNA Genetic Analyzer was used for electrophoresis of the sequence reaction products. The $16 \mathrm{~S}$ rRNA gene sequence of strain IMMIB R-5091 ${ }^{\mathrm{T}}$, as well as those of validly described species of the genus Corynebacterium retrieved from GenBank, were added to the ARB database (Ludwig \& Strunk, 1996) and aligned using the tools of the ARB package. The resulting alignment was corrected manually and evolutionary trees were inferred using maximum-parsimony (Kluge \& Farris, 1969), neighbour-joining (Saitou \& Nei, 1987) and maximum-likelihood (Felsenstein, 1981). An evolutionary distance matrix was calculated using the corrections of Jukes \& Cantor (1969). The tree topology was evaluated according to the results of the neighbourjoining and maximum-likelihood analyses. Phylogenetic analyses were carried out using the ARB package (Ludwig \& Strunk, 1996).

On Columbia blood agar, BHI agar, BHI agar supplemented with $1 \%$ Tween 80 and trypticase soy agar, colonies of strain IMMIB R-5091 ${ }^{\mathrm{T}}$ appeared wrinkly, dry and lightgrey in colour. Cells were non-motile, non-spore-forming, dumbbell-shaped (when examined after $18 \mathrm{~h}$ growth) and at late stages of growth, they showed typical coryneform morphology. Cells stained Gram-positive and non-acid-fast. The organism grew facultatively anaerobically and was catalase-positive but urease-negative. It produced acid from glucose and sucrose, hydrolysed hippurate and displayed alkaline phosphatase, pyrazinamidase, ester lipase (C8), leucine arylamidase and naphthol-AS-BI-phosphohydrolase activities. The organism was negative for all of the other reactions of the API CORYNE, API 20 STREP, API ZYM and MINITEK systems. GC analysis of the end products of glucose fermentation revealed major amounts of lactate.

Chemotaxonomically, strain IMMIB R-5091 ${ }^{\mathrm{T}}$ contained chemical markers that support its assignment to the genus Corynebacterium. The cell wall contained mesodiaminopimelic acid as well as arabinose and galactose (i.e. wall chemotype IV sensu Lechevalier \& Lechevalier, 1970). One-dimensional TLC analysis of whole-cell acid methanolysates of strain IMMIB R-5091 ${ }^{\mathrm{T}}$ revealed the presence of two lipid spots on the chromatogram. The lower one corresponds to corynemycolic acids, as identified by its lower $R_{\mathrm{f}}$ value $(0 \cdot 57)$, and the higher spot corresponds to the non-hydroxylated fatty acids. GC analysis of the non-hydroxylated fatty acid methyl esters revealed the presence of tetradecanoate $(0.47 \%$ of total fatty acids), hexadecenoate $(1.67 \%)$, hexadecanoate $(36.71 \%)$, octadecenoate $(55 \cdot 25 \%)$ and octadecanoate $(5 \cdot 88 \%)$ as major fatty acid methyl esters. Tuberculostearic acid (10-methyl octadecanoate) was not present. Mass spectral analysis of the respiratory quinones showed that strain IMMIB R-5091 ${ }^{\mathrm{T}}$ possessed MK- $7\left(\mathrm{H}_{2}\right)$, MK- $8\left(\mathrm{H}_{2}\right)$ and MK- $9\left(\mathrm{H}_{2}\right)$, with MK-8 $\left(\mathrm{H}_{2}\right)$ as the major component. Polar lipid analysis showed that strain IMMIB R-5091 ${ }^{\mathrm{T}}$ contained diphosphatidylglycerol, phosphatidylinositol and phosphatidylinositol mannoside as characteristic phospholipids, i.e. phospholipid type PI sensu Lechevalier et al. (1977), with no nitrogen-containing phospholipid. The result of triplicate determinations of the $\mathrm{G}+\mathrm{C}$ content of the DNA of strain IMMIB R-5091 ${ }^{\mathrm{T}}$ was $64 \cdot 3 \pm 0 \cdot 7 \mathrm{~mol} \%$.

To ascertain the phylogenetic position of strain IMMIB $\mathrm{R}-5091^{\mathrm{T}}$, its almost complete $16 \mathrm{~S}$ rRNA gene sequence (1466 nt, $95 \cdot 1 \%$ of the Escherichia coli sequence; Brosius et al., 1978) was determined in this study and subjected to a comparative analysis. 16S rRNA gene sequence comparison showed clearly that strain IMMIB $\mathrm{R}-5091^{\mathrm{T}}$ is a member of the family Corynebacteriaceae (Stackebrandt et al., 1997) and that the sequence determined contains all of the signature nucleotides designated for this lineage. The high values for $16 \mathrm{~S}$ rRNA gene sequence similarity to other previously described members of the genus Corynebacterium $(92 \cdot 3-97 \cdot 4 \%)$ support the addition of strain IMMIB R-5091 ${ }^{\mathrm{T}}$ to this genus. Significantly lower levels of relatedness were shown to other taxa of the Actinomycetales (data not shown). Highest sequence relatedness was shown to Corynebacterium afermentans, Corynebacterium riegelii, Corynebacterium sundsvallense and Corynebacterium thomssenii (97-2-97·4\% similarity). The unrooted phylogenetic tree (Fig. 1) was constructed from maximum-parsimony analysis. Sequences that were at least $90 \%$ complete (with regard to E. coli standard sequence) were used for these analyses. The results of maximum-parsimony analysis (Fig. 1) confirmed the association of strain IMMIB R-5091 ${ }^{\mathrm{T}}$ with the genus Corynebacterium. It was evident from the tree that isolate IMMIB R-5091 ${ }^{\mathrm{T}}$ represents a distinct subline within the genus Corynebacterium that is associated with $C$. afermentans, $C$. riegelii, $C$. sundsvallense and $C$. thomssenii. These results suggest that strain IMMIB $\mathrm{R}-5091^{\mathrm{T}}$ belongs to a genetically distinct Corynebacterium species that is closely related to these four species (approx. $2 \cdot 6 \%$ sequence divergence). This sequence divergence is rather low to allow the definition of a novel species, since values below $97 \%$ and/or genomic DNA reassociation values below $70 \%$ are considered as thresholds for the establishment of novel bacterial species (Stackebrandt \& Goebel, 1994). However, the genus Corynebacterium contains a number of species for which numerous distinctive characters have been described that fully justify their classification in separate species, but that exhibit only limited 16S rRNA divergence. For instance, the $16 \mathrm{~S}$ rRNA of Corynebacterium mucifaciens is $98.5 \%$ similar to that of C. afermentans, though distinction between the two species has been illustrated convincingly by different characters and did not require the determination of DNA hybridization values (Funke et al., 1997a). Similarly, Corynebacterium ulcerans, Corynebacterium pseudotuberculosis and Corynebacterium diphtheriae share more than $98 \%$ 16S rRNA similarity (Pascual et al., 1995). More critical examples are Corynebacterium singulare and Corynebacterium minutissimum, the $16 \mathrm{~S}$ rRNA sequences of which are $99 \cdot 1 \%$ similar, 


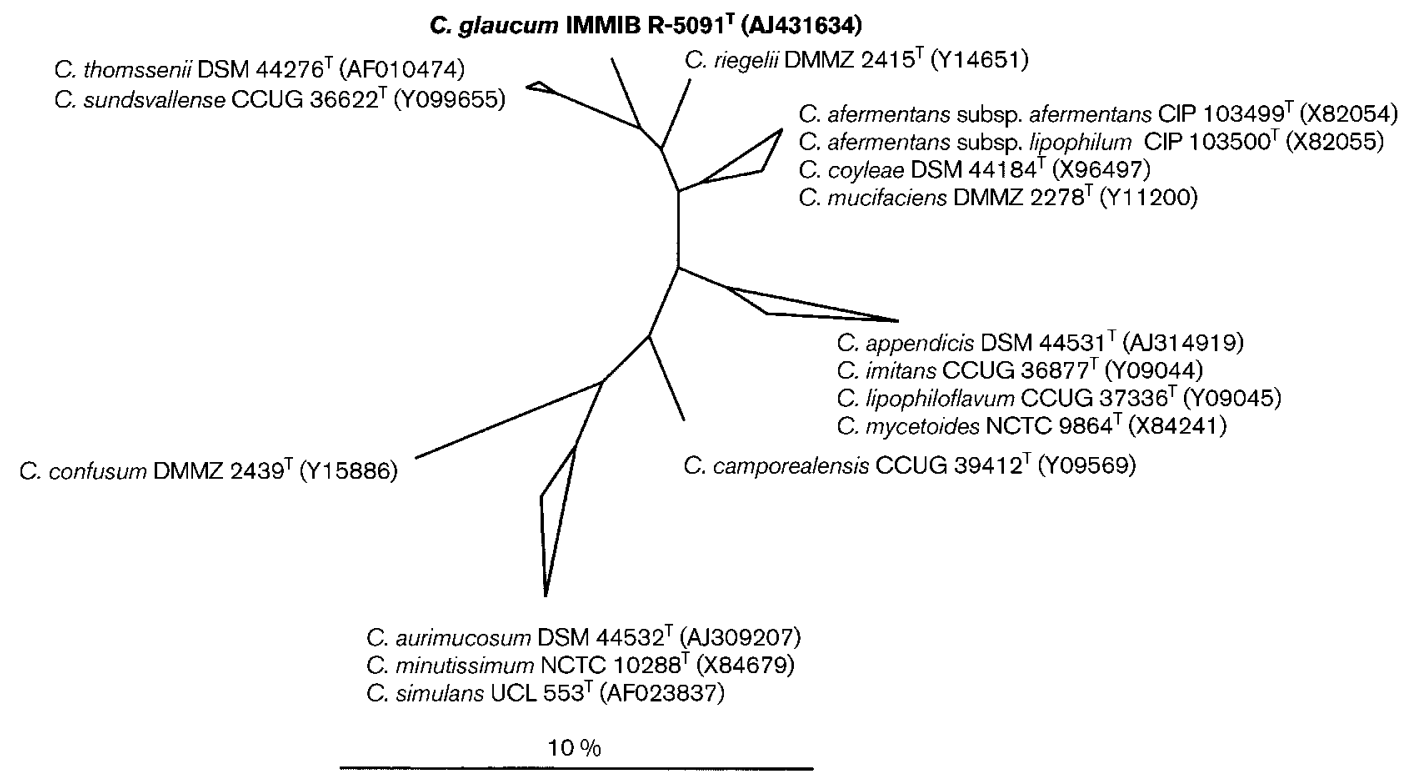

Fig. 1. Maximum-parsimony tree showing the position of strain IMMIB R-5091 ${ }^{\top}$ within the radiation of species of the genus Corynebacterium. Multifurcations indicate tree topologies that could not be resolved significantly using the neighbour-joining and maximum-likelihood algorithms. Bifurcations indicate that stable branching resulted from the various treeing algorithms. The scale bar indicates $10.0 \%$ sequence divergence.

whereas total labelled genomic DNA of the two species exhibited only $28 \%$ relatedness (Riegel et al., 1997). A similar situation is found for Corynebacterium propinquum and Corynebacterium pseudodiphtheriticum, which have a 16S rRNA similarity value of $99 \cdot 4 \%$ (Ruimy et al., 1995) but $25 \%$ DNA-DNA relatedness (Riegel et al., 1993). The $97 \%$ limit is thus not always fulfilled in the genus Corynebacterium and additional distinctive characters must be determined to allow the definition of a novel species. Given the $2 \cdot 6-2 \cdot 8 \%$ sequence divergence of strain IMMIB R- $5091^{\mathrm{T}}$ from its closest relatives C. afermentans, C. riegelii, C. sundsvallense and C. thomssenii on the one hand and the biochemical tests presented in Table 1 to discriminate

Table 1. Differential characteristics of strain IMMIB R-5091 ${ }^{\top}$ and the most closely related Corynebacterium species

Species: 1, C. glaucum IMMIB R-5091 ${ }^{\mathrm{T}}$ sp. nov.; 2, C. riegelii; 3, C. thomssenii; 4, C. sundsvallense; 5, C. afermentans. All strains are negative for acid production from mannose. ND, Not determined.

\begin{tabular}{|lccccc|}
\hline Characteristic & $\mathbf{1}$ & $\mathbf{2}$ & $\mathbf{3}$ & $\mathbf{4}$ & $\mathbf{5}$ \\
\hline Urease & - & + & + & + & - \\
Pyrazinamidase & - & $\mathrm{V}$ & + & $\mathrm{V}$ & - \\
N-Acetyl- $\beta$-glucosaminidase & - & - & + & $\mathrm{ND}$ & - \\
Production of acid from: & & & & & \\
$\quad$ Glucose & + & - & + & + & - \\
$\quad$ Maltose & - & + & + & + & - \\
Sucrose & + & - & + & + & - \\
Ribose & - & + & - & - & - \\
\hline
\end{tabular}

strain IMMIB R-5091 ${ }^{\mathrm{T}}$ from the latter four species on the other, we feel that it is reasonable to define a novel species. Thus, on the basis of the results of our polyphasic taxonomic study, we consider that strain IMMIB R-5091 ${ }^{\mathrm{T}}$ merits classification as a novel species of the genus Corynebacterium, for which the name Corynebacterium glaucum sp. nov. is proposed.

\section{Description of Corynebacterium glaucum sp. nov.}

Corynebacterium glaucum (glau'cum. L. neut. adj. glaucum bluish, light-grey, pertaining to the appearance of colonies).

Cells are Gram-positive and non acid-alcohol-fast. They are non-motile, non-spore-forming and dumbbell-shaped (when examined after $18 \mathrm{~h}$ growth), showing typical coryneform morphology (when examined after 1 week of growth). On Columbia blood agar supplemented with $5 \%$ sheep blood, BHI agar and trypticase soy agar, colonies are light-grey in colour. Grows facultatively anaerobically and is catalase-positive. It contains meso-diaminopimelic acid as the wall diamino acid in addition to galactose and arabinose in whole-cell hydrolysates (i.e. cell-wall chemotype IV). Contains corynemycolic acids and the fatty acid profile contains saturated and unsaturated fatty acids. Tuberculostearic acid is absent. Contains MK-7 $\left(\mathrm{H}_{2}\right)$, MK$8\left(\mathrm{H}_{2}\right)$ and MK-9 $\left(\mathrm{H}_{2}\right)$ as respiratory menaquinones, with MK-8 $\left(\mathrm{H}_{2}\right)$ as the major component. Phospholipid pattern type PI, with no nitrogen-containing compounds. Produces acid from glucose and sucrose but not from arabinose, cellobiose, glycerol, glycogen, inulin, lactose, maltose, 
mannitol, raffinose, rhamnose, ribose, salicin, sorbitol, trehalose or xylose. Hydrolyses hippurate but not aesculin, gelatin or starch. Displays alkaline phosphatase, pyrazinamidase, ester lipase (C8), leucine arylamidase and naphtholAS-BI-phosphohydrolase activities but is negative for acid phosphatase, arginine dihydrolase, cystine arylamidase, esterase (C4), lipase (C14), $\alpha$-glucosidase, $\beta$-glucosidase, $\alpha$-galactosidase, $\beta$-galactosidase, $\beta$-glucuronidase, $N$-acetyl $\beta$ glucosaminidase, $\alpha$-mannosidase, $\alpha$-fucosidase, pyrrolidonyl arylamidase, valine arylamidase, trypsin, chymotrypsin, nitrate reductase and urease. Acetoin production is positive but indole production is negative. Produces lactate as the major product of glucose fermentation. The $\mathrm{G}+\mathrm{C}$ content of the type strain is $64 \cdot 3 \mathrm{~mol} \%$.

The type strain, strain IMMIB R-5091 ${ }^{\mathrm{T}}$ (=DSM $44530^{\mathrm{T}}$ $=$ NRRL B- $24142^{\mathrm{T}}$ ), was isolated from a cosmetic dye.

\section{References}

Becker, B., Lechevalier, M. P., Gordon, R. E. \& Lechevalier, H. A. (1964). Rapid differentiation between Nocardia and Streptomyces by paper chromatography of whole cell hydrolysates. Appl Microbiol 12, 421-423.

Brennan, N. M., Brown, R., Goodfellow, M., Ward, A. C., Beresford, T. P., Simpson, P. J., Fox, P. F. \& Cogan, T. M. (2001). Corynebacterium mooreparkense sp. nov. and Corynebacterium casei sp. nov., isolated from the surface of a smear-ripened cheese. Int J Syst Evol Microbiol 51, 843-852.

Brosius, J., Palmer, M. L., Kennedy, P. J. \& Noller, H. F. (1978). Complete nucleotide sequence of the 16S ribosomal RNA gene from Escherichia coli. Proc Natl Acad Sci U S A 75, 4801-4805.

Collins, M. D., Pirouz, T., Goodfellow, M. \& Minnikin, D. E. (1977). Distribution of menaquinones in actinomycetes and corynebacteria. J Gen Microbiol 100, 221-230.

Collins, M. D., Goodfellow, M. \& Minnikin, D. E. (1982a). A survey of the structures of mycolic acids in Corynabacterium and related taxa. J Gen Microbiol 128, 129-149.

Collins, M. D., Goodfellow, M. \& Minnikin, D. E. (1982b). Fatty acid composition of some mycolic acid-containing coryneform bacteria. J Gen Microbiol 128, 2503-2509.

Collins, M. D., Hoyles, L., Hutson, R. A., Foster, G. \& Falsen, E. (2001). Corynebacterium testudinoris sp. nov., from a tortoise, and Corynebacterium felinum sp. nov., from a Scottish wild cat. Int J Syst Evol Microbiol 51, 1349-1352.

Felsenstein, J. (1981). Evolutionary trees from DNA sequences: a maximum likelihood approach. J Mol Evol 17, 368-376.

Fernández-Garayzábal, J. F., Collins, M. D., Hutson, R. A., Gonzalez, I., Fernández, E. \& Domínguez, L. (1998). Corynebacterium camporealensis sp. nov., associated with subclinical mastitis in sheep. Int J Syst Bacteriol 48, 463-468.

Funke, G., Von Graevenitz, A., Clarridge, J. E., III \& Bernard, K. A. (1997a). Clinical microbiology of coryneform bacteria. Clin Microbiol Rev 10, 125-159.

Funke, G., Lawson, P. A. \& Collins, M. D. (1997b). Corynebacterium mucifaciens sp. nov., an unusual species from human clinical material. Int J Syst Bacteriol 47, 952-957.

Funke, G., Lawson, P. A. \& Collins, M. D. (1998). Corynebacterium riegelii sp. nov., an unusual species isolated from female patients with urinary tract infections. J Clin Microbiol 36, 624-627.
Holdeman, L. V., Cato, E. P. \& Moore, W. E. C. (1977). Anaerobic Laboratory Manual, 4th edn. Blacksburg, VA: Virginia Polytechnic Institute and State University.

Jukes, T. H. \& Cantor, C. R. (1969). Evolution of protein molecules. In Mammalian Protein Metabolism, pp. 21-132. Edited by H. N. Munro. New York: Academic Press.

Keddie, R. M. \& Cure, G. L. (1977). The cell wall composition and distribution of free mycolic acids in named strains of coryneform bacteria and in isolates from various natural sources. J Appl Bacteriol 42, 229-252.

Kluge, A. G. \& Farris, F. S. (1969). Quantitative phyletics and the evolution of anurans. Syst Zool 18, 1-32.

Lechevalier, M. P. (1968). Identification of aerobic actinomycetes of clinical importance. J Lab Clin Med 71, 934-944.

Lechevalier, M. P. \& Lechevalier, H. (1970). Chemical composition as a criterion in the classification of aerobic actinomycetes. Int J Syst Bacteriol 20, 435-443.

Lechevalier, M. P., de Bièvre, C. \& Lechevalier, H. A. (1977). Chemotaxonomy of aerobic actinomycetes: phospholipid composition. Biochem Syst Ecol 5, 249-260.

Ludwig, W. \& Strunk, O. (1996). ARB, a software environment for sequence data. http://www.mikro.biologie.tu-muenchen.de/pub/ ARB/documentation/arb.ps

Mesbah, M., Premachandran, U. \& Whitman, W. B. (1989). Precise measurement of the $\mathrm{G}+\mathrm{C}$ content of deoxyribonucleic acid by highperformance liquid chromatography. Int J Syst Bacteriol 39, 159-167. Minnikin, D. E., Hutchinson, I. G., Caldicott, A. B. \& Goodfellow, M. (1980). Thin-layer chromatography of methanolysates of mycolic acid-containing bacteria. J Chromatogr 188, 221-223.

Pascual, C., Lawson, P. A., Farrow, J. A. E., Navarro Gimenez, M. \& Collins, M. D. (1995). Phylogenetic analysis of the genus Corynebacterium based on $16 \mathrm{~S}$ rRNA gene sequences. Int $J$ Syst Bacteriol 45, 724-728.

Rainey, F. A., Ward-Rainey, N., Kroppenstedt, R. M. \& Stackebrandt, E. (1996). The genus Nocardiopsis represents a phylogenetically coherent taxon and a distinct actinomycete lineage: proposal of Nocardiopsaceae fam. nov. Int J Syst Bacteriol 46, 1088-1092.

Riegel, P., de Briel, D., Prévost, G., Jehl, F. \& Monteil, H. (1993). Proposal of Corynebacterium propinquum sp. nov. for Corynabacterium group ANF-3 strains. FEMS Microbiol Lett 113, 229-234.

Riegel, P., Ruimy, R., Renaud, F. N. R., Freney, J., Prevost, G., Jehl, F., Christen, R. \& Monteil, H. (1997). Corynebacterium singulare sp. nov., a new species for urease-positive strains related to Corynebacterium minutissimum. Int J Syst Bacteriol 47, 1092-1096.

Ruimy, R., Riegel, P., Boiron, P., Monteil, H. \& Christen, R. (1995). Phylogeny of the genus Corynebacterium deduced from analyses of small-subunit ribosomal DNA sequences. Int J Syst Bacteriol 45, 740-746.

Saitou, N. \& Nei, M. (1987). The neighbor-joining method: a new method for reconstructing phylogenetic trees. Mol Biol Evol 4, 406425.

Schleifer, K. H. \& Kandler, O. (1972). Peptidoglycan types of bacterial cell walls and their taxonomic implications. Bacteriol Rev 36, 407-477.

Stackebrandt, E. \& Goebel, B. M. (1994). Taxonomic note: a place for DNA-DNA reassociation and $16 \mathrm{~S}$ rRNA sequence analysis in the present species definition in bacteriology. Int J Syst Bacteriol 44, 846-849.

Stackebrandt, E., Rainey, F. A. \& Ward-Rainey, N. L. (1997). Proposal for a new hierarchic classification system, Actinobacteria classis nov. Int J Syst Bacteriol 47, 479-471. 
Wattiau, P., Janssens, M. \& Wauters, G. (2000). Corynebacterium simulans sp. nov., a non-lipophilic, fermentative Corynebacterium. Int J Syst Evol Microbiol 50, 347-353.

Yassin, A. F. (1988). Chemotaxonomic Untersuchungen zur vereinfachten Differenzierung und Identifizierung von aeroben Aktinomyzeten und Mykobakterien. Inaaugural-Dissertation zur Erlangung des Doktorgrades der Methematische-Naturwissenschaftlichen Fakultät der Rheinischen friedrich-Wilhelms-Universität Bonn.
Yassin, A. F., Haggenei, B., Budzikiewicz, H. \& Schaal, K. P. (1993). Fatty acid and polar lipid composition of the genus Amycolatopsis: application of fast atom bombardment-mass spectrometry to structure analysis of underivatized phospholipids. Int $J$ Syst Bacteriol 43, 414-420.

Yassin, A. F., Rainey, F. A., Burghardt, J., Brzezinka, H., Mauch, M. \& Schaal, K. P. (2000). Nocardia paucivorans sp. nov. Int J Syst Evol Microbiol 50, 803-809. 